\title{
Umbilical Cord Derived Mesenchymal Stem Cells Useful in Insulin Production - Another Opportunity in Cell Therapy
}

\author{
Shabari Sarang, Chandra Viswanathan \\ Reliance Life Sciences Pot Ltd., Dhirubhai Ambani Life Sciences Centre, Navi Mumbai, India
}

Background and Objectives: Type 1 Diabetes Mellitus (T1DM) is an autoimmune disorder resulting out of T cell mediated destruction of pancreatic beta cells. Immunomodulatory properties of mesenchymal stem cells may help to regenerate beta cells and/or prevent further destruction of remnant, unaffected beta cells in diabetes. We have assessed the ability of umbilical cord derived MSCs (UCMSCs) to differentiate into functional islet cells in vitro.

Methods and Results: We have isolated UCMSCs and allowed sequential exposure of various inducing agents and growth factors. We characterized these cells for confirmation of the presence of islet cell markers and their functionality. The spindle shaped undifferentiated UCMSCs, change their morphology to become triangular in shape. These cells then come together to form the islet like structures which then grow in size and mature over time. These cells express pancreatic and duodenal homeobox -1 (PDX-1), neurogenin 3 (Ngn-3), glucose transporter 2 (Glut 2) and other pancreatic cell markers like glucagon, somatostatin and pancreatic polypeptide and lose expression of MSC markers like CD73 and CD105. They were functionally active as demonstrated by release of physiological insulin and C-peptide in response to elevated glucose concentrations.

Conclusions: Pancreatic islet like cells with desired functionality can thus be obtained in reasonable numbers from undifferentiated UCMSCs invitro. This could help in establishing a "very definitive source" of islet like cells for cell therapy. UCMSCs could thus be a game changer in treatment of diabetes.

Keywords: Mesenchymal stem cells, Stem cells, Type 1 Diabetes, Umbilical cord derived MSCs (UCMSCs)

\section{Introduction}

Type 1 Diabetes Mellitus (T1DM) is one of the most prevalent of all metabolic disorders caused by autoimmune destruction of insulin secreting beta islet cells. Loss of beta $(\beta)$ cells leads to insufficient or totally absent

Accepted for publication February 14, 2016, Published online May 30, 2016 Correspondence to Shabari Sarang

Reliance Life Sciences Pvt Ltd., Dhirubhai Ambani Life Sciences Centre, R/282, MIDC area of TTC, Thane Belapur Road, Rabale, Navi Mumbai 400701, India

Tel: +91-22-67678436, Fax: +91-22-67678099

E-mail: shabari.tipnis@relbio.com

(a) This is an open-access article distributed under the terms of the Creative Commons Attribution Non-Commercial License (http://creativecommons.org/ licenses/by-nc/4.0/), which permits unrestricted non-commercial use, distribution, and reproduction in any medium, provided the original work is properly cited. insulin levels and poor glycemic control, which in turn may lead to numerous microvascular and macro-vascular complications. It is observed that significant mortality and morbidity is much higher in the affected population. The prevalence of diabetes at all age groups world-wide has been predicted to reach to about $10 \%$ by $2,030(1,2)$.

Currently, insulin replacement via exogenously administered insulin is the most preferred kind of T1DM treatment. Insulin therapy maintains the blood glucose levels at acceptable level and has been credited with improved survival and relatively lesser complications. The efforts to ameliorate TIDM by transplanting isolated pancreatic islets have been attempted since 1970s. But the problem has been of limited engraftment and uncertain availability of islets. This therapy moreover, requires additional multiple daily injections of insulin as well as major lifestyle modifications. 
Activation of islet cell antigen reactive $\mathrm{T}$ cells is the first step towards destruction of islet cells. T1DM results from destruction of insulin-producing pancreatic $\beta$ cells by a $\beta$ cell-specific autoimmune process. $\beta$ cell auto-antigens are thought to be released from $\beta$ cells by cellular turnover or damage and are processed and presented to $\mathrm{T}$ helper cells by antigen-presenting cells (APCs). These $\mathrm{CD}^{+} \mathrm{T}$ cells can be activated by interleukin (IL)-12 released from macrophages and dendritic cells. While this process takes place, $\beta$ cell antigen-specific $\mathrm{CD}^{+} \mathrm{T}$ cells are activated by IL- 2 produced by the activated TH1 $\mathrm{CD}^{+}{ }^{+}$Tcells and differentiate into cytotoxic Tcells which are recruited into the pancreatic islets. These activated $\mathrm{TH} 1 \mathrm{CD}^{+}{ }^{+}$Tcells and $\mathrm{CD} 8^{+}$cytotoxic Tcells are involved in the destruction of $\beta$ cells. In addition, $\beta$ cells can also be damaged by granzymes and perforin released from $\mathrm{CD}^{+}$cytotoxic $\mathrm{T}$ cells. Thus, activated macrophages, $\mathrm{TH} 1 \mathrm{CD}^{+} \mathrm{T}$ cells, and $\beta$ cell-cytotoxic $\mathrm{CD} 8^{+} \mathrm{T}$ cells act synergistically to destroy $\beta$ cells, resulting in autoimmune T1DM (3).

Understanding well these short comings, a therapeutic approach aimed at regenerating insulin producing cells to prevent autoimmune destruction of residual and newly forming $\beta$ cells, is the strategy to be adopted. All these positive effects may be brought in by the use of stem cells.

Several published literature reports have stated that human embryonic stem cells (hESCs), umbilical cord blood hematopoietic stem cells (HSCs), induced pluripotent stem cells (iPSCs) and mesenchymal stem cells (MSCs) have potentials to be differentiated into insulin producing cells in vitro (4-8). The significance of adult stem cells, more specifically MSCs needs no further demonstration on its being a potential cell type for considerations in clinical use (9).

Potential of MSCs to trans-differentiate into other cell types such as $\beta$ islet cells was considered to be their major regenerative potential, but more recent evidence indicates that MSCs carry out tissue repair processes by actually migrating to the site of tissue injury and participating in the repair processes by mechanisms such as secreting cytokines and other paracrine factors (1). Further, MSCs have also been shown to possess immunoregulatory capacity, both in vitro as well as in vivo, as they can modulate many functions of immune cells including $\mathrm{T}$ cells, B cells, dendritic cells (DCs) and NK cells (10). In this regard, MSCs are being tried in preclinical animal studies and clinical trials in treatment of GvHD and autoimmune diseases, such as Multiple Sclerosis, Systemic Lupus Erythematosus and Crohn's disease, with varying observations (11-13). As expected, MSCs have also not shown any tumour formation after transplantation.

Until recently, bone marrow derived MSCs have dominated the market as an important stem cell source, with its own limitations. It has requirement for an invasive harvesting procedure and the cell quality and the ability of proliferation is dependant on the age and health of the donor. Umbilical cord derived MSCs (UCMSCs) are probably more superior because of their relatively high yield of younger cells from a naive source (14-18). Needless to say, sourcing these is not a challenge, as cord tissues are normally discarded. The ability of UCMSCs to differentiate to mesodermal lineages as well as neural lineage has already been well documented (19). Other studies have shown that UCMSCs express nestin as a mesenchymal maker (20-22) and these nestin positive stem cells isolated from the adult pancreatic islets have been shown to differentiate ex vivo into pancreatic endocrine, exocrine and hepatic progenitors (23). The nestin positive cells are the cells that migrate from the pancreatic bud, hence these group of cells can be the starting cells for pancreatic islet differentiation.

MSCs have been shown to be able to differentiate to insulin producing cells (IPCs) by using specific culture media. IPC identification is further based on their ability to express genes related to pancreatic development and function (24). IPCs have been obtained from bone marrow MSCs using a high glucose culture medium (25) or nicotinamide enriched medium $(21,26)$ to promote cell differentiation. MSCs have also been shown to get differentiated to IPC by a three stage protocol, involving the use of nicotinamide, activin $\mathrm{A}$ and beta cellulin in high glucose concentration (27). Karnieli et al. has even used a PDX-1 gene transfer approach to obtain differentiated beta islet cells (28).

In the present study, we have differentiated UCMSCs to pancreatic progenitor cells in vitro. We have shown the expression of differentiated pancreatic cell markers on these cells and also confirmed their functionality in vitro which we narrate in greater details in passages below. Our cells, on differentiation express, high levels of Insulin and C-peptide along with expression of other pancreatic cell markers like glucagon, somatostatin and Glut-2. They are also very strongly positive for Ngn-3. These differentiated cells are further able to respond to high glucose conditions and release higher levels of insulin and C-peptide in vitro.

\section{Materials and Methods}

\section{Isolation and expansion of UCMSCs}

Umbilical cords were collected from healthy volunteer 
mothers after administering an informed consent, as per the recommendations of the institutional ethics committee. MSCs were isolated from umbilical cords using an in-house established and published protocol (4).

Briefly, the cord was cleaned with PBS (Invitrogen, CA, USA) containing antibiotics. The blood clots were removed and the cord was dissected into smaller explants and placed on tissue culture dishes in expansion media (DMEM/F12 [Invitrogen, CA, USA] with 10\% FBS (Hyclone, South Logan, UT) and $2 \mathrm{ng} / \mathrm{ml}$ basic FGF [R\&D systems, USA]). The cells were allowed to grow out from the explants, expanded in monolayers at $37^{\circ} \mathrm{C}$ and $5 \% \mathrm{CO}_{2}$ and supplemented with fresh media every alternate day. The cells were routinely subcultured every $5 \sim 6$ days and characterized at every passage. Only UCMSCs from passage 2 to 5 were used for all the experiments.

\section{In vitro differentiation of UCMSCs to pancreatic progenitor cells}

UCMSCs were cultured in DMEM/Ham's F12 medium (Lonza, Singapore) containing basic FGF (R\&D systems, USA) with sequential addition of insulin, transferrin, selenium, taurine and glucagon-like peptide -1 (GLP-1) (Sigma, USA) for a period of 2 weeks at $37^{\circ} \mathrm{C}$ and $5 \% \mathrm{CO}_{2}$. During the process of differentiation, the cells were monitored for a change in morphology. At the end of the 15 day differentiation protocol, they were collected and characterized for specific cellular markers.

\section{Characterization of cells}

The differentiated cells were analysed for expression of insulin and Ngn-3 by immunostaining. The cells were cultured on glass sides and on differentiation were stained with anti-insulin and anti-Ngn-3 after permeabilization and fixing of the cells. The labelled cells were observed under the microscope.

The differentiated cells were collected using Tryple Select (Life Technologies, USA) dissociation medium and characterized for cellular markers by immunophenotyping. The levels of CD73 (BD Biosciences, USA), CD105 (R\&D systems, USA), insulin, C-peptide, glucagon, PDX-1, somatostatin, pancreatic polypeptide, Glut-2 and Ngn-3 (all antibodies from Chemicon) were studied. Data was analysed using Cell Quest software.

\section{Molecular Characterization of cells}

The undifferentiated cells, the pancreatic progenitor cells and the differentiated cells were subjected to RNA isolation (Qiagen, USA), followed by cDNA synthesis (Invitrogen, Singapore) for reverse transcriptase-PCR
Table 1. Primer details

\begin{tabular}{lll}
\hline Primer name & \multicolumn{1}{c}{ Primer sequence } & Length \\
\hline GAPDH & F-5'TGAAGGTCGGAGTCAACGG3' & $500 \mathrm{bp}$ \\
& R-5'CATGTGGGCCATGAGGTCCA3' & \\
\multirow{2}{*}{ Ngn-3 } & F-5'GTCCCTCTACTCCCCAGTC3' & $383 \mathrm{bp}$ \\
& R-5'CTCAAGCAGGCGCGGAAAG3' & \\
PDX-1 & F-5'AGCTTACAAGGACCCATGC3' & \multirow{2}{*}{$415 \mathrm{bp}$} \\
& R-5'TTCAACATGACAGCCAGCTC3' & \\
\multirow{2}{*}{ Insulin } & F-5'AGCCTTGTGAACCAACAC3' & \multirow{2}{*}{$460 \mathrm{bp}$} \\
& R-5'GCTGGTAGAGGGAGCAGAT3' & \\
\hline
\end{tabular}

(RT-PCR) as per the manufacturer's instructions. The PCR was set up using primers for GAPDH (internal control), Ngn-3, PDX-1 and Insulin. Briefly, the denaturation was done at $94^{\circ} \mathrm{C}$ for 30 secs, annealing at $60^{\circ} \mathrm{C}$ for $45 \mathrm{sec}-$ onds according to the requirement of the primers, extension at $72^{\circ} \mathrm{C}$ for 30 seconds, the final extension at $72^{\circ} \mathrm{C}$ for 10 mins and at the end of the reaction, the products were set up to hold at $4^{\circ} \mathrm{C}$. The number of cycles was maintained at 30 . The primers and their product lengths are listed in Table 1. The amplified cDNA was analysed by electrophoresis on $1.5 \%$ agarose gel.

\section{In-vitro Functionality assays}

The differentiated cells were plated on 24 well plates for studying insulin and the C-peptide release. The cells were washed with DPBS and supplemented with $10 \mathrm{mM} / \mathrm{L}$ HEPES and either $5.5 \mathrm{mM}$ glucose (low glucose) or 25 $\mathrm{mM}$ glucose (high glucose) at $37^{\circ} \mathrm{C}$ for 1 hour. The supernatant was collected and the insulin released in the supernatant was quantified using human Insulin ELISA kit (Mercodia, Sweden). The same supernatants were also analysed for amount of C-peptide released using Human ultrasensitive C-peptide detection kit. The absorbance for both was read at $450 \mathrm{~nm}$ using an ELISA plate reader.

\section{Measurement of staged C-peptide secretion}

For stage specific C-peptide release assay, the cells were cultured in the above mentioned differentiation media. The conditioned medium was collected intermittently and quantified using the Human ultra sensitive C-peptide detection kit (Mercodia, Sweden). The absorbance was read at $450 \mathrm{~nm}$ using an ELISA plate reader.

\section{Statistical Analysis}

The statistical analysis of data was performed using Student's paired two-tailed t-test to determine statistical significance. Values are given as mean $\pm \mathrm{SD}$. The statistical analysis was done for comparing the release of insulin by undifferentiated UCMSCs and pancreatic progenitor cells 
under low glucose and high glucose concentrations. Also a statistical analysis was done for release of c-peptide by the two cell types under the similar culture conditions.

\section{Results}

\section{Pancreatic progenitors from UCMSCs}

The undifferentiated UCMSCs are seen as spindle shaped cells under the microscope. But during differentiation, they lose their spindle morphology and start becoming more triangular. The edges become curved and slowly the cells start coming together, which is termed as the "cell walking' in the culture dishes. As the differentiation protocol progresses, the cells start forming small islet like clusters which gradually increase in size (Fig. 1). Once formed, these islet like clusters remain stable in cultures for atleast one month without change in their characteristics and functionality, when fresh media was continuously replenished every $3^{\text {rd }}$ day.

\section{Characterization of pancreatic progenitors}

The undifferentiated UCMSCs, as expected were positive for CD73, CD105 and were negative for CD45 and
CD34 cell surface markers. However, after differentiation, these cells lost their MSC markers. They gradually started expressing the markers specific for the pancreatic lineage including the early markers like the PDX-1 and Ngn3, and the mid and late markers like the insulin, C-peptide, Glut-2, glucagon and somatostatin (Fig. 2A). More than $85 \%$ of the differentiated cells are positive for Ngn-3. Low expression of pancreatic polypeptide (PP) was also observed post differentiation. This showed that the differentiation protocol supported the formation of all the cell types, the alpha, delta and PP cells along with the major population of beta cells. The alpha cells secrete glucagon, while the delta cells are responsible for release of somatostatin. The PP cells release functionally active pancreatic polypeptide. These supporting cells have been hypothesized to be required for proper functioning of the differentiated cells in vivo.

The cells were also characterized by immunostaining. It was observed that the cells were positive for insulin and Ngn-3 (Fig. 2B).

Ngn-3 (383 bp) was strongly expressed in the undifferentiated and the progenitor stage, while it reduced as the cells differentiate, since this is an early stage marker.

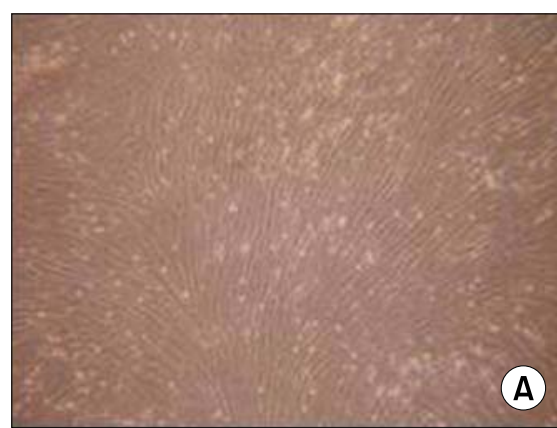

UCMSCs, day 0

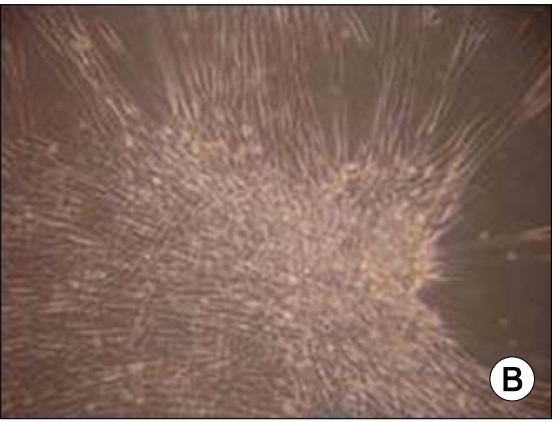

UCMSCs, day 10

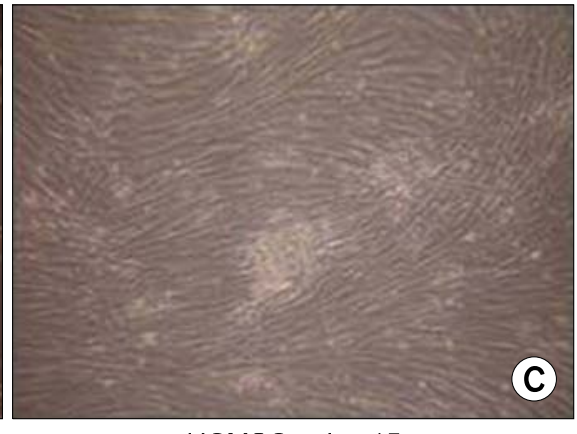

UCMSCs, day 15

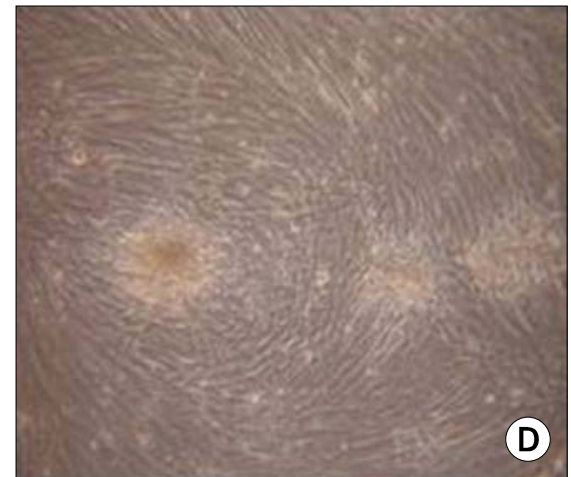

UCMSCs, day 18

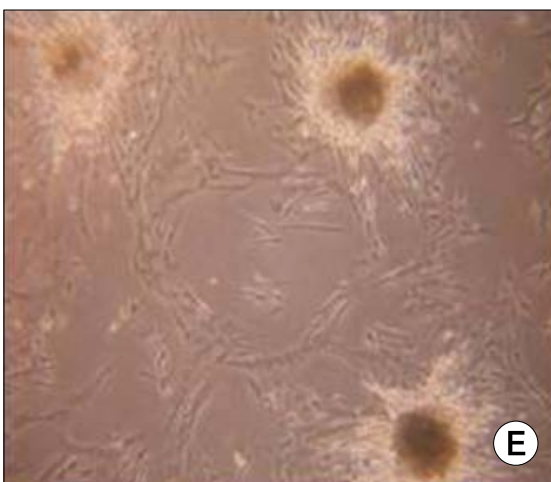

UCMSCs, day 21

Fig. 1. Morphology of differentiating cells. (A) Undifferentiated UCMSCs. (B) Cells coming together on the culture dishes. (C) Formation of small islet like clusters on the culture dishes. (D, E) The islet like clusters grow in size over the culture period. 
A
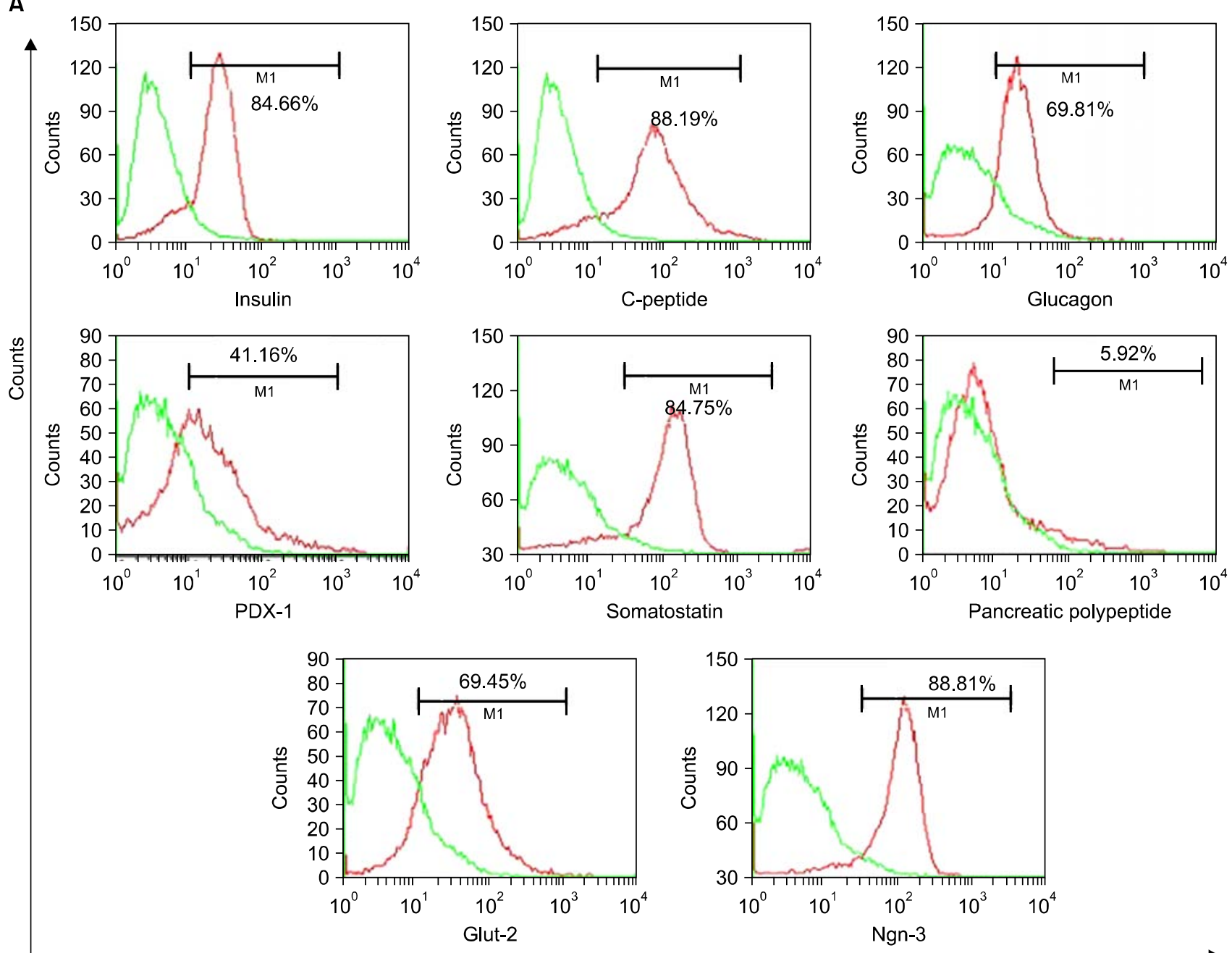

Fluorescence

B

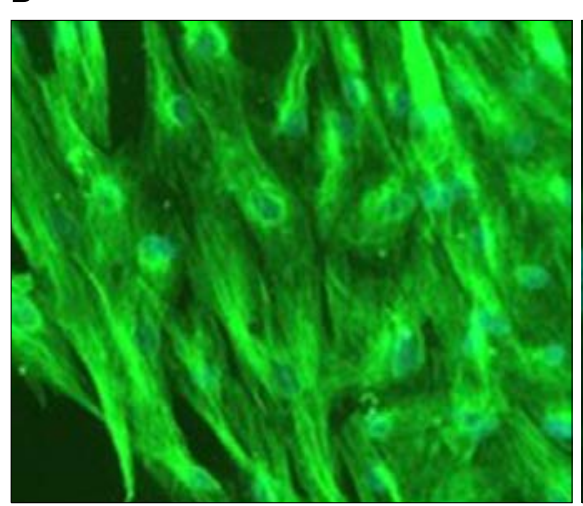

Insulin+DAP |

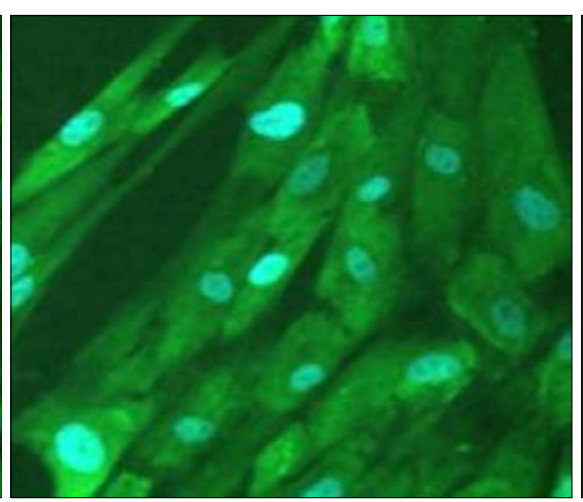

Ngn-3+DAPI

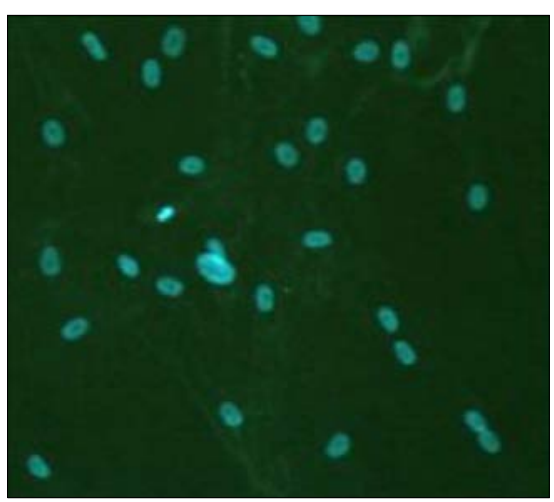

Sec. control+DAPI

Fig. 2. Characterization of cells from the islet like clusters obtained in the culture dishes by (A) immunophenotyping and (B) immunostaining.

Light band of PDX-1 (415 bp) was observed only in the undifferentiated cells, which was lost over differentiation. Insulin (460 bp), which is a confirmatory marker for pan- creatic cells, was very clearly observed at all the stages of the differentiation process (Fig. 3). 


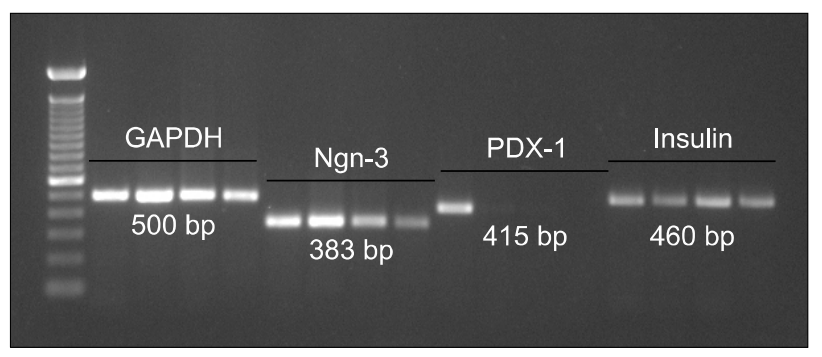

Fig. 3. Molecular characterization of cells. Lane 1: 100 bp ladder. Lane 2, 6, 10, 14: Undifferentiated MSCs. Lane 3, 7, 11, 15: Progenitor cells. Lane 4, 8, 12, 16: 1 week post maturation. Lane 5, 9, 13, 17: 1 month post maturation.

\section{A}

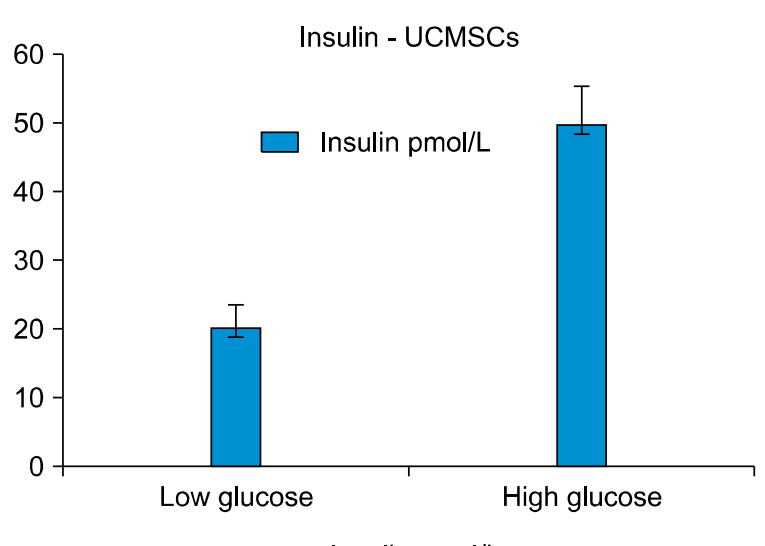

C

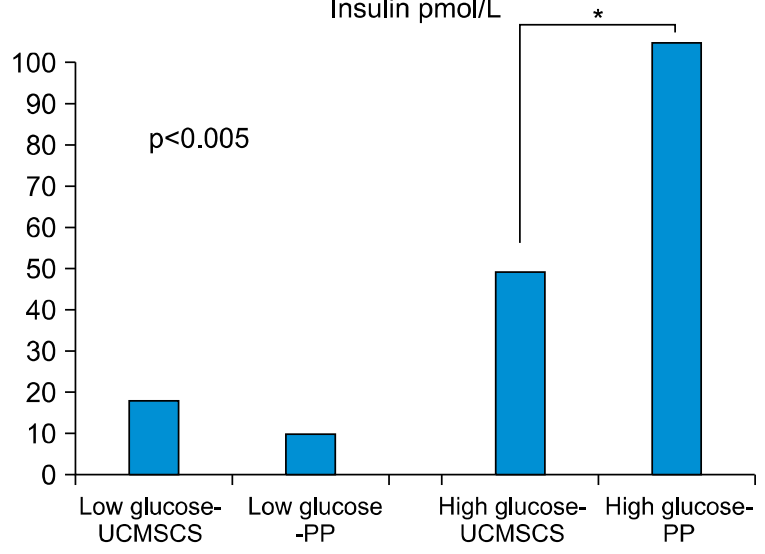

E

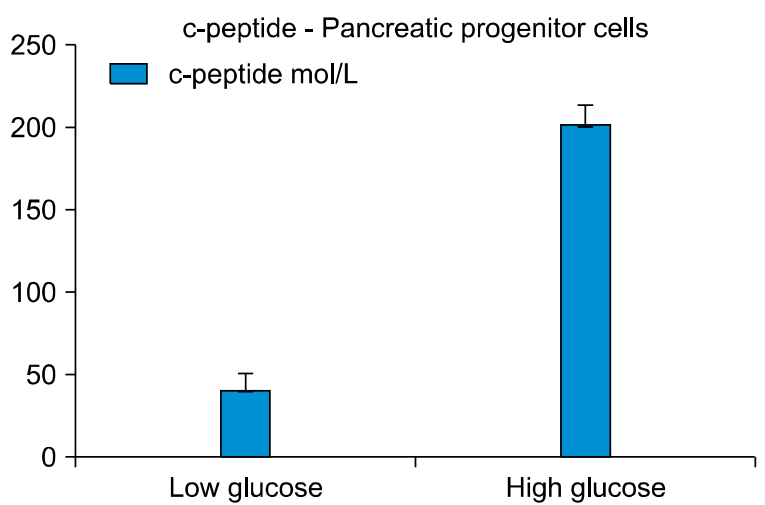

\section{Detection of Insulin released by differentiated cells}

The differentiated pancreatic progenitor cells, containing approximately 50 islet like clusters, obtained from initial seeding of 1 million UCMSCs, when stimulated with high glucose $(25 \mathrm{mM})$ for a period of 1 hour, released insulin in the supernatant. This was estimated by ELISA and observed to be on an average $100 \mathrm{pmol} / \mathrm{L}$ as against $12 \mathrm{pmol} / \mathrm{L}$ released by same number of islet like clusters exposed to a lower glucose stimulus (5.5 mM) (Fig. 4).

The undifferentiated UCMSCs, however released on an average $20 \mathrm{pmol} / \mathrm{L}$ insulin in an unstimulated state, while
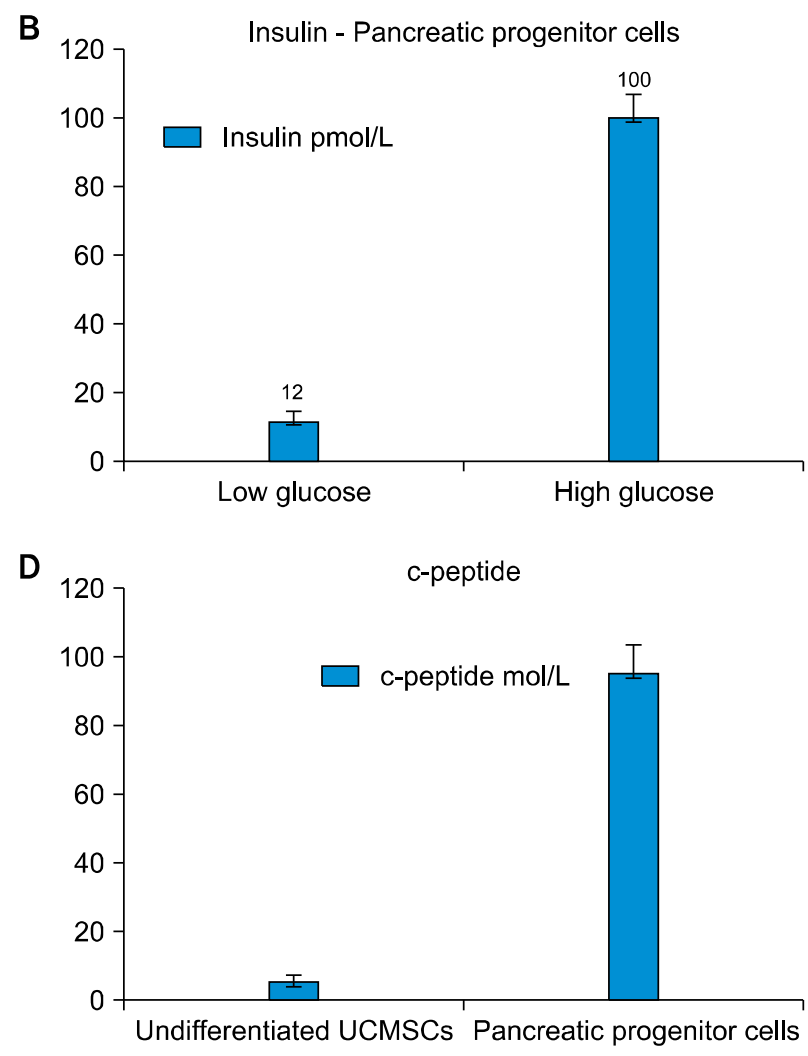

Fig. 4. Detection of Insulin and c-peptide in the culture supernatant. (A) Undifferentiated UCMSCs release insulin differently in response to low glucose and high glucose concentrations. (B) Differentiated pancreatic progenitor cells release insulin under high glucose insult. (C) Comparative analysis of the insulin released by the two cell types under low glucose and high glucose concentrations. The difference between the insulin released by undifferentiated UCMSCs and the pancreatic progenitors (PP) is statistically significant ( $p$ value $<$ 0.005). (D) Differentiated pancreatic progenitor cells release c-peptide. (E) High c-peptide released by pancreatic progenitor cells under high glucose conditions. 
those exposed to high glucose released about $50 \mathrm{pmol} / \mathrm{L}$ of insulin.

\section{Detection of c-peptide released by the differentiated cells}

Since there is controversy regarding possible insulin uptake by cells from media supplements that may be difficult to distinguish from insulin produced by the cells, we have used human C-peptide as an indicator of insulin production by our cells (29). The concentration of C-peptide in the undifferentiated and the differentiated cells, measured by ELISA, showed that the differentiated pancreatic progenitor cells secreted higher levels of C-peptide (95 $\mathrm{mM})$, than the undifferentiated UCMSCs (5 $\mathrm{mM})$.

These cells were also analyzed for their ability to respond to the glucose challenge in vitro. As shown in the Fig. 4 approximately 50 islet like clusters secreted 40 $\mathrm{pmol} / \mathrm{L}$ of C-peptide at low $(5.5 \mathrm{mM})$ glucose which increased to about $200 \mathrm{pmol} / \mathrm{L}$ at a high glucose concentration $(25 \mathrm{mM})$.

\section{Discussion}

In the present study, our focus was to evaluate the potential of UCMSCs to differentiate into functional pancreatic islet like cells. We have successfully shown that the UCMSCs are able to differentiate to pancreatic islet like cells and express multiple markers related to development and function of pancreatic islet cells including good expression of markers for beta islet cells. These cells were also able to release insulin in response to glucose in a dose dependant manner.

With respect to growth conditions used for cell differentiation, the major concern has always been the requirement for animal free media and the cost of the differentiation. In this direction, literature shows that successful yields have been obtained using conditioned medium from various other cell types. Chao et al., have shown earlier the differentiation potential of Wharton jelly derived MSCs to pancreatic ILCs (Islet like cells) using neuronal conditioned medium (30). However, using conditioned medium from a different cell lineage may have diverse implications on the diseased individual when they are used for therapy. Moreover, the growth factors that have been used are also extremely costly, further making the differentiation protocol impossible to be used for obtaining required numbers of cells.

Kadam et al., have showed differentiation using a protocol similar to our protocol, but they have not confirmed the changes at the cellular and molecular levels (31). The differentiation potential was lost during the culture period. We have been able to overcome these limitations and reduce the time and obtain higher numbers of cells in cheaper growth media using a ten day protocol. This helps in obtaining higher numbers in a much lesser time and cost.

The basic requirements for surrogate beta cells are the ability to process proinsulin into insulin, maintain low basal insulin secretion and physiologically regulated insulin secretion in response to glucose. Therefore, the number of islets secreting specified concentration of insulin needs to be calculated to understand the number of islets that may be required for transplantation during therapy. Physiologically, a typical blood level of insulin between the meals is $60 \sim 80 \mathrm{pmol} / \mathrm{L}$. We, in this study have calculated all the concentrations using a standard number of islets to give a comparative analysis. We have been able to show that about 50 islets, each islet consisting of approximately $80 \sim 100$ million cells, are capable of expressing $100 \mathrm{pmol} /$ litre of insulin in the presence of glucose. This can help us with extrapolation for calculations regarding the number of islets that may be required for an individual depending on this body weight and the location of transplantation. If the transplantation is intra-pancreatic, then 50 islets may be efficacious, but if the islets are to be administered via the intraveneous route, more numbers of islets may be required for the possibility to let abundant cells to reach the site of action. Moreover, using our media, we have been able to show the functionality of the differentiated islets, in vitro, for an extended period of 3 weeks. Clinical transplantation of cadaveric islets, which includes beta cells, has provided the proof of concept for replacement therapy for diabetes and is the rationale for developing beta cells from pluripotent stem cells. More than 20 years of experience in improving cadaveric islet transplantation has provided insights into the number of islet equivalents required, the site of transplantation, delivery and immunosuppression regimens (32).

The maintenance of blood sugar levels is important for the normal physiology of the body and this homeostasis is maintained using a feedback system in which insulin and glucagon have key roles (25). The effects of glucagon are the opposite of the effects induced by insulin. The two hormones need to work in partnership with each other to keep blood glucose levels balanced. Glucagon plays an active role in allowing the body to regulate the utilization of glucose and fats. Hence, it is very essential to have the alpha cells secreting glucagon along with the beta cells secreting insulin during transplantation. Few earlier studies have shown that insulin alone is unable to be functional 
under stressed conditions physiologically. Three failed clinical trials have been reported using stem cells for the treatment of Type 1 Diabetes, one of them being the trial conducted by Osiris Therapeutics, the second by Juvenile Diabetes Research Foundation (JDRF) and University of Florida and the third by Tehran University (33). All these trials have been unable to fulfil the primary endpoint of reduction in C-pepdide levels. It is postulated that this essentially is due to inability of the cells to balance the homeostasis. Hence, it is very essential to have cells expressing glucagon as well. Our study shows that about 60 $\sim 70 \%$ of cells express glucagon after differentiation. This has not yet been shown by other in vitro studies.

Majority of our cells express Ngn-3. Ngn3 belongs to the basic helix-loop-helix (bHLH) class of transcription factors and functions primarily as an activator of gene transcription in endocrine progenitor cells. It is expressed in a small percentage of cells within the developing pancreas consisting of endocrine progenitor cells, and functions to directly enhance the expression of the lineage-committed transcription factors required for the differentiation of the endocrine progenitor cells into each of the endocrine cell subtypes. Ngn3 binds directly to the promoters of the $\beta$ cell specific transcription factors b2/NeuroD and Pax4 to promote the differentiation of progenitor cells into the $\beta$ cell lineage $(34,35)$. Ngn3 expression is extinguished coincident with the expression of the endocrine hormones that define the endocrine lineages, for example the insulin expression in beta cells.

Earlier, Rajagopal et al. have observed that the beta like cells differentiated from the stem cells did not produce insulin, but merely took it up from the media and subsequently appeared positive for insulin via biochemistry (36). These false positive signals have been taken note of. We have therefore confirmed the presence of C-peptide, which is a marker for residual insulin production by the cells of interest in the culture dishes. We have been able to confirm about $95 \%$ positivity of C-peptide in our cultures, which establish that the insulin identified by ELISA is the one that is produced by our cells and not a result of uptake.

In our study we have been able to show positivity of all the beta islet cells like the insulin, PDX-1 and Ngn-3 along with the other supporting cells which have been positive for glucagon, somatostatin and pancreatic polypeptide. These are the markers which have also been shown to be the markers of interest by other groups working on the pancreatic differentiation of the stem cells. In addition, Kadam et al., have shown the cells expressing Isl-1 which is also constitutively expressed by the stem cells in undifferentiated cells (37). The expression is maintained throughout the differentiation protocol and is not lost by the terminally differentiated cells as well. Hence, the marker may not hold significance to confirm the differentiation potential of these cells.

The most important advantage of our protocol is that these cells are being differentiated from UCMSCs, which are immunoprivileged cells (10). Moreover these cells are also immunosuppressive as shown by our group in our previous publications. This aspect of MSCs would be very helpful in treating diabetes, as it is believed to be an autoimmune disease. So modulating the immune status is also one of the approaches of this disorder.

Thus, our study shows that beta cells can be derived from MSCs, from the Umbilical cord tissue. These pancreatic islet like differentiated cells are capable of production and secretion of physiologically active insulin when cultured under high glucose conditions. The short differentiation protocol further helps in making the required numbers of cells available easily within a span of $2 \sim 3$ weeks of requirement for cell based treatment of diabetes. Our differentiation protocol has also been able to provide for differentiated cells which are stable for longer durations in vitro. It may also be clinically more relevant, because use of allogeneic MSCs, like the UCMSCs may help them to evade the destruction by the host immune system.

\section{Acknowledgments}

This work is supported and funded by the management team of Reliance Life Sciences Pvt. Ltd. We acknowledge and thank Dr. Prathibha Shetty for her continuous support during the entire study and for critically reviewing the manuscript.

\section{Potential conflict of interest}

The authors have no conflicting financial interest.

\section{References}

1. Hematti P, Kim J, Stein AP, Kaufman D. Potential role of mesenchymal stromal cells in pancreatic islet transplantation. Transplant Rev (Orlando) 2013;27:21-29

2. Hu J, Yu X, Wang Z, Wang F, Wang L, Gao H, Chen Y, Zhao W, Jia Z, Yan S, Wang Y. Long term effects of the implantation of Wharton's jelly-derived mesenchymal stem cells from the umbilical cord for newly-onset type 1 diabetes mellitus. Endocr J 2013;60:347-357

3. Yoon JW, Jun HS. Autoimmune destruction of pancreatic beta cells. Am J Ther 2005;12:580-591

4. Shetty P, Cooper K, Viswanathan C. Comparison of proliferative and multilineage differentiation potentials of cord 
matrix, cord blood, and bone marrow mesenchymal stem cells. Asian J Transfus Sci 2010;4:14-24

5. Basford CL, Prentice KJ, Hardy AB, Sarangi F, Micallef SJ, Li X, Guo Q, Elefanty AG, Stanley EG, Keller G, Allister EM, Nostro MC, Wheeler MB. The functional and molecular characterisation of human embryonic stem cell-derived insulin-positive cells compared with adult pancreatic beta cells. Diabetologia 2012;55:358-371

6. Koblas T, Zacharovová K, Berková Z, Leontovic I, Dovolilová E, Zámecník L, Saudek F. In vivo differentiation of human umbilical cord blood-derived cells into insulin-producing beta cells. Folia Biol (Praha) 2009;55: 224-232

7. Kunisada Y, Tsubooka-Yamazoe N, Shoji M, Hosoya M. Small molecules induce efficient differentiation into insulin-producing cells from human induced pluripotent stem cells. Stem Cell Res 2012;8:274-284

8. Wang HS, Shyu JF, Shen WS, Hsu HC, Chi TC, Chen CP, Huang SW, Shyr YM, Tang KT, Chen TH. Transplantation of insulin-producing cells derived from umbilical cord stromal mesenchymal stem cells to treat NOD mice. Cell Transplant 2011;20:455-466

9. Viswanathan C, Shetty P. Clinical safety and efficacy of autologous mesenchymal stem cells in spinal cord injury: A clinical trial report. Advances of Stem Cells 2013. doi: 10.5171/2013.679731

10. Tipnis S, Viswanathan C, Majumdar AS. Immunosuppressive properties of human umbilical cord-derived mesenchymal stem cells: role of B7-H1 and IDO. Immunol Cell Biol 2010;88:795-806

11. Shi Y, Hu G, Su J, Li W, Chen Q, Shou P, Xu C, Chen X, Huang Y, Zhu Z, Huang X, Han X, Xie N, Ren G. Mesenchymal stem cells: a new strategy for immunosuppression and tissue repair. Cell Res 2010;20:510-518

12. Yagi H, Soto-Gutierrez A, Parekkadan B, Kitagawa Y, Tompkins RG, Kobayashi N, Yarmush ML. Mesenchymal stem cells: Mechanisms of immunomodulation and homing. Cell Transplant 2010;19:667-679

13. Sioud M. New insights into mesenchymal stromal cellmediated T-cell suppression through galectins. Scand J Immunol 2011;73:79-84

14. Zhou H, Guo M, Bian C, Sun Z, Yang Z, Zeng Y, Ai H, Zhao RC. Efficacy of bone marrow-derived mesenchymal stem cells in the treatment of sclerodermatous chronic graft-versus-host disease: clinical report. Biol Blood Marrow Transplant 2010;16:403-412

15. Prasad VK, Lucas KG, Kleiner GI, Talano JA, Jacobsohn D, Broadwater G, Monroy R, Kurtzberg J. Efficacy and safety of ex vivo cultured adult human mesenchymal stem cells $\left(\right.$ Prochymal $^{\mathrm{TM}}$ ) in pediatric patients with severe refractory acute graft-versus-host disease in a compassionate use study. Biol Blood Marrow Transplant 2011;17:534-541

16. Karussis D, Karageorgiou C, Vaknin-Dembinsky A, Gowda-Kurkalli B, Gomori JM, Kassis I, Bulte JW, Petrou P, Ben-Hur T, Abramsky O, Slavin S. Safety and immunological effects of mesenchymal stem cell transplantation in patients with multiple sclerosis and amyotrophic lateral sclerosis. Arch Neurol 2010;67:1187-1194

17. Liang J, Zhang H, Hua B, Wang H, Lu L, Shi S, Hou Y, Zeng X, Gilkeson GS, Sun L. Allogenic mesenchymal stem cells transplantation in refractory systemic lupus erythematosus: a pilot clinical study. Ann Rheum Dis 2010;69: 1423-1429

18. Duijvestein M, Vos AC, Roelofs H, Wildenberg ME, Wendrich BB, Verspaget HW, Kooy-Winkelaar EM, Koning F, Zwaginga JJ, Fidder HH, Verhaar AP, Fibbe WE, van den Brink GR, Hommes DW. Autologous bone marrow-derived mesenchymal stromal cell treatment for refractory luminal Crohn's disease: results of a phase I study. Gut 2010;59:1662-1669

19. Shetty P, Ravindran G, Sarang S, Thakur AM, Rao HS, Viswanathan C. Clinical grade mesenchymal stem cells transdifferentiated under xenofree conditions alleviates motor deficiencies in a rat model of Parkinson's disease. Cell Biol Int 2009;33:830-838

20. Fu YS, Cheng YC, Lin MY, Cheng H, Chu PM, Chou SC, Shih YH, Ko MH, Sung MS. Conversion of human umbilical cord mesenchymal stem cells in Wharton's jelly to dopaminergic neurons in vitro: potential therapeutic application for Parkinsonism. Stem Cells 2006;24:115-124

21. Chen LB, Jiang XB, Yang L. Differentiation of rat marrow mesenchymal stem cells into pancreatic islet beta-cells. World J Gastroenterol 2004;10:3016-3020

22. Ma L, Feng XY, Cui BL, Law F, Jiang XW, Yang LY, Xie QD, Huang TH. Human umbilical cord Wharton's Jelly-derived mesenchymal stem cells differentiation into nerve-like cells. Chin Med J (Engl) 2005;118:1987-1993

23. Zulewski H, Abraham EJ, Gerlach MJ, Daniel PB, Moritz W, Müller B, Vallejo M, Thomas MK, Habener JF. Multipotential nestin-positive stem cells isolated from adult pancreatic islets differentiate ex vivo into pancreatic endocrine, exocrine, and hepatic phenotypes. Diabetes 2001;50:521-533

24. Tang DQ, Cao LZ, Burkhardt BR, Xia CQ, Litherland SA, Atkinson MA, Yang LJ. In vivo and in vitro characterization of insulin-producing cells obtained from murine bone marrow. Diabetes 2004;53:1721-1732

25. Oh SH, Muzzonigro TM, Bae SH, LaPlante JM, Hatch HM, Petersen BE. Adult bone marrow-derived cells trans-differentiating into insulin-producing cells for the treatment of type I diabetes. Lab Invest 2004;84:607-617

26. Wu XH, Liu CP, Xu KF, Mao XD, Zhu J, Jiang JJ, Cui D, Zhang M, Xu Y, Liu C. Reversal of hyperglycemia in diabetic rats by portal vein transplantation of islet-like cells generated from bone marrow mesenchymal stem cells. World J Gastroenterol 2007;13:3342-3349

27. Sun Y, Chen L, Hou XG, Hou WK, Dong JJ, Sun L, Tang KX, Wang B, Song J, Li H, Wang KX. Differentiation of bone marrow-derived mesenchymal stem cells from diabetic patients into insulin-producing cells in vitro. Chin Med J (Engl) 2007;120:771-776

28. Karnieli O, Izhar-Prato Y, Bulvik S, Efrat S. Generation of 
insulin-producing cells from human bone marrow mesenchymal stem cells by genetic manipulation. Stem Cells 2007;25:2837-2844

29. Gjessing HJ, Matzen LE, Faber OK, Frøland A. Sensitivity and reproducibility of urinary C-peptide as estimate of islet B-cell function in insulin-treated diabetes. Diabet Med 1989;6:329-333

30. Chao KC, Chao KF, Fu YS, Liu SH. Islet-like clusters derived from mesenchymal stem cells in Wharton's Jelly of the human umbilical cord for transplantation to control type 1 diabetes. PLoS One 2008;3:e1451

31. Kadam SS, Bhonde RR. Islet neogenesis from the constitutively nestin expressing human umbilical cord matrix derived mesenchymal stem cells. Islets 2010;2:112-120

32. Sidhu KS. Frontiers in pluripotent stem cell research and therapeutic potentials Bench to Bedside. Dubai: Bentham Science Publishers; 2012. ISBN 1608052893, 9781608052899.

33. Bersenev A. Stem cell therapy of type 1 diabetes - recent failed trials. Cell Trials Current Trends in Cell Therapy, 2012.

34. Huang HP, Liu M, El-Hodiri HM, Chu K, Jamrich M, Tsai MJ. Regulation of the pancreatic islet-specific gene BETA2 (neuroD) by neurogenin 3. Mol Cell Biol 2000;20:3292-3307

35. Smith SB, Gasa R, Watada H, Wang J, Griffen SC, German MS. Neurogenin3 and hepatic nuclear factor 1 cooperate in activating pancreatic expression of Pax4. J Biol Chem 2003;278:38254-38259

36. Rajagopal J, Anderson WJ, Kume S, Martinez OI, Melton DA. Insulin staining of ES cell progeny from insulin uptake. Science 2003;299:363

37. Kadam S, Muthyala S, Nair P, Bhonde R. Human placenta-derived mesenchymal stem cells and islet-like cell clusters generated from these cells as a novel source for stem cell therapy in diabetes. Rev Diabet Stud 2010;7: 168-182 